\title{
Trajectories of obstetric nurses in the care of planned home childbirth: oral history
}

\author{
Trajetórias de enfermeiras obstetras no atendimento ao \\ parto domiciliar planejado: história oral \\ Trayectorias de enfermeras obstétricas en el cuidado del \\ parto domiciliario planificado: historia oral
}

\author{
Luciana Makarevicz Santos ${ }^{a}$ \\ Júnia Aparecida Laia da Mata ${ }^{b}$ \\ Alessandra Vaccarib \\ Clara Fróes de Oliveira Sanfelice ${ }^{c}$
}

\begin{abstract}
How to cite this article: Santos LM, Mata JAL, Vaccari A, Sanfelice CF0. Trajectories of obstetric nurses in the care of planned home childbirth: oral history. Rev Gaúcha Enferm. 2021;42(spe):e20200191. doi: https://doi.org/10.1590/19831447.2021.20200191
\end{abstract}

Universidade Federal do Rio Grande do Sul (UFRGS), Escola de Enfermagem. Porto Alegre, Rio Grande do Sul, Brasil.

b Universidade Federal do Rio Grande do Su (UFRGS), Escola de Enfermagem, Departamento de Enfermagem Materno-infantil. Porto Alegre, Rio Grande do Sul, Brasil.

Universidade Estadual de Campinas (UNICAMP), Faculdade de Enfermagem, área de Saúde da Mulher e do Recém-nascido. Campinas, São Paulo, Brasil.

\section{ABSTRACT}

Objective: To describe the trajectory of the insertion of obstetric nurses in the care of planned home childbirth in Rio Grande do Sul. Method: An exploratory and qualitative study, with application of thematic oral history. Thirteen obstetric nurses who worked in planned home childbirth in the state participated in the study. Data was collected from December 2019 to March 2020 through interviews and analyzed based on a thematic content analysis.

Results: Two categories emerged: 1) Personal, training and professional experiences that encouraged obstetric nurses to enter planned home childbirth; and 2) The search for autonomy, freedom, protagonism and respect in the care of delivery and birth as stimuli for the insertion of obstetric nurses in the planned home childbirth.

Conclusion: Personal, training and professional experiences and dissatisfaction with hospital obstetric care in the state, considered interventionist and physician-centered, encouraged obstetric nurses to enter planned home childbirth.

Keywords: Nursing. Obstetrics. Home childbirth.

\section{RESUMO}

Objetivo: Descrever a trajetória da inserção de enfermeiras obstetras no atendimento ao parto domiciliar planejado no Rio Grande do Sul.

Método: Estudo exploratório, qualitativo, com aplicação da história oral temática. Participaram treze enfermeiras obstetras que atuavam no parto domiciliar planejado no estado. Os dados foram coletados de dezembro/2019 a março/2020, por meio de entrevistas, e analisados com base na análise temática de conteúdo.

Resultados: Emergiram duas categorias: 1) Experiências pessoais, formativas e profissionais que impulsionaram as enfermeiras obstetras a ingressarem no parto domiciliar planejado; e 2) A busca por autonomia, liberdade, protagonismo e respeito na atenção ao parto e nascimento como propulsores para a inserção das enfermeiras obstetras no parto domiciliar planejado.

Conclusão: As experiências pessoais, formativas e profissionais e o descontentamento com a atenção obstétrica hospitalar no estado, considerada intervencionista e centrada no médico, foram propulsores para as enfermeiras obstetras inserirem-se no parto domiciliar planejado.

Palavras-chave: Enfermagem. Obstetrícia. Parto domiciliar.

\section{RESUMEN}

Objetivo: Describir la trayectoria de la inserción de enfermeras obstétricas en el cuidado del parto domiciliario planificado en Rio Grande do Sul.

Método: Estudio exploratorio y cualitativo, con aplicación de historia oral temática. Trece enfermeras obstétricas que trabajaron en el parto domiciliario planificado en el estado participaron en el estudio. Los datos se recopilaron entre diciembre de 2019 y marzo de 2020, a través de entrevistas, y se analizaron sobre la base del análisis de contenido temático.

Resultados: Surgieron dos categorías: 1) Experiencias personales, formativas y profesionales que alentaron a las enfermeras obstétricas a entrar en el parto domiciliario planificado; y 2) La búsqueda de la autonomía, la libertad, el protagonismo y el respeto en el cuidado del parto y el nacimiento como propulsores para la inserción de enfermeras obstétricas en el parto domiciliario planificado. Conclusión: Experiencias personales, formativas y profesionales y descontento con la atención obstétrica hospitalaria en el estado, considerada intervencionista y centrada en el médico, impulsaron la entrada de las enfermeras obstétricas en el parto domiciliario planificado.

Palabras clave: Enfermería. Obstetricia. Parto domiciliario. 


\section{口INTRODUCTION}

The overview of births in Brazil reveals the predominance of their occurrence at hospitals and the increasing use of cesarean sections. Recent data of the Unified Health System Information Technology Department (Departamento de Informática do Sistema Único de Saúde, DATASUS) showed that, in 2018, $98 \%$ of the births happened at hospitals, and only $0.6 \%$ at homes, $55.9 \%$ being through cesarean sections ${ }^{(1)}$. Such indicators show how much the technocratic paradigm, which uses high technology in assistance processes and deals with the body and the mind in a fragmented manner ${ }^{(2)}$, predominates in Brazilian Obstetrics.

On the other hand, nurses and obstetricians have dedicated themselves to serve the home parturition process in a planned manner. This professional category can assist vaginal delivery with normal physiological evolution and neonates; and promote an assistance model, centered on the woman, as well as an environment favorable to vaginal delivery, according to Resolution No. 516/2016 of the Federal Council of Nursing (Conselho Federal de Enfermagem, COFEN) ${ }^{(3)}$.

Nurses and obstetricians usually offer private planned home childbirth based on scientific evidence and international guidelines, as the Unified Health System (Sistema Único de Saúde, SUS) does not have protocols or normatives so far subsidizing the professionals that provide this service in the country ${ }^{(4)}$.

Planned home childbirth is a care/birth modality indicated to normal-risk pregnant women who want to give birth at their homes in a scheduled manner, and by qualified professionals $s^{(5)}$. It is a tradition in countries like the Netherlands, Canada, and Australia, being recognized and encouraged by their public health systems ${ }^{(4)}$. In Brazil, planned home childbirth is not covered by the Unified Health System (SUS).

The Brazilian Ministry of Health $(\mathrm{MoH})$ recommends that humanized care for delivery and birth be guaranteed to women and newborns, respecting the good practices recommended by the World Health Organization (WHO), which include the provision of viable delivery and birth assistance, where the woman has a choice and feels comfortable. However, planned home childbirth is not part of the list of the SUS procedures. There are also no national indicators related to this birth modality, which makes it difficult to know its reality.

Within this context, it was considered relevant to study the planned home childbirth assisted by nurses and obstetricians, having the following guiding question: How, when, and why do nurses and obstetricians start providing assistance to planned home childbirth?
The State of Rio Grande do Sul (RS), Brazil, was defined as the study locus. According to the DATASUS ${ }^{(1)}$, in 2018, the number of live births in RS was 140,052. Of this total, $99 \%(139,450)$ were born in hospitals, and only $0.26 \%(367)$ corresponded to home childbirths. Regarding the type of birth, $62 \%(87,583)$ were through cesarean section, and $37 \%(52,448)$ through vaginal delivery ${ }^{(1)}$, elucidating how much obstetric assistance in that region has been predominantly hospital-, surgical-, and technocratic-based.

It is not possible to verify in the DATASUS if home childbirths were planned or not, reinforcing the importance of this research in explaining the overview of the professionals who provide this type of assistance in a Brazilian state.

Given the preceding information, this study aims at describing the insertion trajectory of obstetric nurses in the assistance to planned home childbirth in Rio Grande do Sul.

\section{METHODS}

This was a research study of the exploratory type, with a quantitative approach. Exploratory research studies explain a new theme, collaborating to subsequent studies related to it ${ }^{(6)}$.

The study locus was the state Rio Grande do Sul. Before the research development, an empirical-exploratory survey of the planned home childbirth's teams in RS was carried out to verify their viability through the world wide web, on a search engine, and two social media. Five groups were identified and, subsequently, the researchers made telephone contacts with them from December 2018 and February 2019. Based on these contacts, 13 EOs (for Obstetric Nurses, "Enfermeiras Obstetras" in Portuguese) were verified in the assistance to planned home childbirth. It is emphasized that the EOs have contact with each other, keeping a communication network and, for this reason, they confirmed if the number of teams was the one identified by the authors, which confirmed the initial finding. These data were not changed during the research.

The data survey was developed through audio-recording interviews, applying the thematic oral history method (self-reporting), with the support of two guiding scripts, a general one, in which there was information regarding the women's characterization and guiding questions, addressing the professional participation in planned home childbirth, and an individual one (with information related to training, professional practice, and personal experiences), prepared through a biographical survey of the professionals who agreed to participate in the study ${ }^{(7)}$. 
The oral history method studies historical developments, institutions, social groups, and professional categories, focused on testimonies through interviews of those who participated or witnessed them. It results from a relationship between history and their sociocultural environment, recovering what was lived according to what was conceived by who experienced it. Oral history contributions are always more significant in areas little studied and explored ${ }^{(8)}$, such as the theme of the present study when Brazil is considered.

After the EOs agreed to participate, and the Free and Informed Consent was signed, the interviews were scheduled and applied based on the scripts. They were applied individually from December 2019 to March 2020 by the first author of this work, supported by a digital recorder.

The professionals had two options to be interviewed: in person (at home, at work, or other preferred location) or through videoconference, by using the Skype ${ }^{\circledR}$ software. These were determined according to the choice of each participant. The remote interview option was offered due to the fact that the EOs have an irregular work routine in planned home childbirth, and this option facilitated their participation in the research.

Five interviews were conducted in person, two in the city of Pelotas and three in Porto Alegre, with the locations previously defined by the volunteers, and eight through videoconference. The commuting for data collection was directly funded by the researchers.

Data analysis and interpretation were based on the Thematic Content Analysis proposed by Laurence Bardin("), being applied simultaneously with data collection. It involves a set of communication analysis techniques that aims at obtaining, through systematic and objective procedures of the content description of indicators (quantitative or qualitative), the production conditions of variables/phenomena, enabling the interference of relative knowledge ${ }^{(9)}$.

The stages of this analysis method are organized into three chronological poles: pre-analysis, exploration of the material, and analysis and interpretation ${ }^{(9)}$. In the first, the floating reading of the material collected and the data selection to be submitted for analysis were conducted.

In the second, the findings were codified, turning them into context units (sentences or words) to describe the relevant characteristics of the content ${ }^{(9)}$. In the third stage, the results were synthesized in large categories of analysis, being interpreted based on the scientific literature on the theme ${ }^{(9)}$.

This research was analyzed and approved by the Research Commission of the Nursing School (record No. 37726), of the Federal University of Rio Grande do Sul (Universidade
Federal do Rio Grande do Sul, UFRGS), and by its Research Ethics Committee (Comitê de Ética em Pesquisa, CEP) (CAAE: 21165219.9.0000.5347). The participants' identification was coded as follows to preserve their anonymity: EO1, EO2, EO3... EO13. All the ethical precepts set forth in Resolution No. 510/2016 of the National Health Council ${ }^{(10)}$ were respected.

\section{RESULTS AND DISCUSSION}

\section{Categorization of the Participants}

In Chart 1 we present the categorization of the study participants.

All the participants were female. Most of the EOs (11) were registered as specialists in the Regional Nursing Council (Conselho Regional de Enfermagem, COREN) of RS, and those who were not (2), reported as a reason the fact that they had just concluded their specialization. It is important to highlight that all the professionals who assist planned home childbirth must have prior registration with their Professional Counci( ${ }^{(4)}$.

When asked about having worked as nurses in different obstetric areas, five answered no, and eight mentioned the following areas: primary care, operating room, intensive care, emergency room, surgical and clinical hospitalization, pediatrics, and psychiatry. Six of the 13 interviewees worked exclusively with planned home childbirth and eight with different primary care hospital areas.

\section{Analysis Categories}

In this section, the two analysis categories that emerged from the context units extracted from the data will be presented, namely: 1) Personal, training, and professional experiences that encouraged the obstetric nurses to start working with planned home childbirth in RS; 2) The search for autonomy, freedom, protagonism, and respect in labor and birth care as stimuli for the insertion of obstetric nurses in planned home childbirth.

\section{Personal, training and professional experiences that encouraged obstetric nurses to start working with planned home childbirth in RS.}

The discourses elucidated that the participant's training, personal, and professional experiences encouraged their insertion in planned home childbirth. 


\begin{tabular}{|c|c|c|c|c|}
\hline Participants & $\begin{array}{c}\text { Nursing training } \\
\text { time }\end{array}$ & $\begin{array}{l}\text { Obstetric Nursing } \\
\text { training time }\end{array}$ & $\begin{array}{l}\text { Modality of Obstetric } \\
\text { Nursing training }\end{array}$ & $\begin{array}{l}\text { Time working in } \\
\text { planned home } \\
\text { childbirth in RS }\end{array}$ \\
\hline E01 & 11 years & 8 years & Specialization & 6 years \\
\hline EO2 & 11 years & 5 years & Specialization & 5 years \\
\hline EO3 & 4 years & 2 years & Residency & 1 year and 6 months \\
\hline EO4 & 9 years & 2 years & Specialization & 1 year and 6 months \\
\hline EO5 & 5 years & 2 years & Residency & 1 year and 6 months \\
\hline E06 & 9 years & 2 years & Specialization & 1 year and 6 months \\
\hline EO7 & 6 years & 4 years & Residency & 4 years \\
\hline EO8 & 8 years & 2 years & Specialization & 1 year and 8 months \\
\hline EO9 & 6 years & 4 years & Specialization & 5 years \\
\hline E010 & 10 years & 7 years & Specialization & 4 years \\
\hline E011 & 2 years & 8 months & Residency & 8 months \\
\hline E012 & 3 years & 8 months & Specialization & 1 year \\
\hline E013 & 4 years & 1 year and 6 months & Residency & 1 year and 3 months \\
\hline
\end{tabular}

Chart 1 - Characterization of the study participants. Porto Alegre, 2020

Source: Research data, 2020.

I started working with home childbirth with my own home childbirth! [...] When I started the postgraduate program in obstetrics, I didn't know so much about this world of home childbirth, during the program [postgraduate program] I started knowing a little about vaginal delivery, seeing the natural process and I saw that, wow, why are we losing this? Then I started rescuing a lot of things. In the middle of the program [postgraduate program] I got pregnant[...] and then I came up with the idea of having a home childbirth. We studied a lot with my husband. I went to conversation circles. [...] I met some girls at this moment, I was pregnant. I created a connection with them and, after my daughter was born, we got delighted. Then, my husband said: Well, then, when does she enter the team? Because EO10 said "look, we have a vacancy", and I was always like "let's see" and it was like this. After my daughter was born, I though carefully about the subject, that I wanted to go into. Anyway, know more. [...] And then I got into the team. (EO6)

The speech above reveals that, based on a personal experience of planning the home childbirth and giving birth at her home, EO6 felt motivated to start assisting this method, offering to women what she had already positively experienced, even with the encouragement of her partner. A positive experience in the parturition process causes emotions, satisfaction, and empowerment in women ${ }^{(11-12)}$. In this case, EO6 got empowered to the extent that she decided to work in a theoretically little-known area for her at that time but deeply experienced in her parturition process.

The support of the professionals who assisted EO6 and the relationship established among them may also have cooperated for her to see herself as a nurse working with planned home childbirth. These are elements that favor the 
motherhood experience ${ }^{(11)}$ and, probably, also encouraged the nurse to join the team that assisted her.

We verified that most of the volunteers' Nursing training, in undergraduate and specialization courses, did not approach planned home childbirth. The following speech is highlighted to show this finding:

In my specialization, no one has ever talked about home childbirth, neither in undergraduate course. So, I never had contact with that, it was never mentioned in classes, nothing about it. But during specialization, a colleague already had some familiarity with that, from hearing about it. [...] Anyway, she invited us for [a course with] a Mexican midwife, Naoli Vinaver, who would come to offer some training. I think it was a four-day training to talk about her practice and how it was, and then I went there, without many expectations. I went to learn something different. And when she started to talk about her work, with home childbirth, in a way with such a strong connection with this work, with so much emotion involved, focused on natural things, on physiology. I had an awakening. During that weekend, I thought: oh my God, this is what I want to do, this is what I have to do. (EO1)

As mentioned by EO1, the contact with the theme happened in a specific training session with an international midwife, Naoli Vinaver, who has spread knowledge about planned home childbirth in Brazil and, probably, influenced many professionals regarding this practice.

In 2014, I had some training with Naoli. They were 3 days that changed everything! I saw that it was in home childbirth that I was going to find what I was looking for. (EO10)

The residency in Obstetric Nursing was an encouragement to EOs to enter this area.

The Sofia [Sofia Feldman Hospital] was a really really crazy thing and changed my life, because until now, then, we say it's very difficult to talk about how our experience was in the residency [Sofia Feldman Hospital], only who goes through it can understand, you know? How crazy it is to intensely live the 60 weekly hours of a residency in a place where you work so hard, you know? With this assistance [to humanized childbirth]. What I had experienced here in Rio Grande do Sul, you know? What the doulas course brought me was only the tip of the iceberg. In the Sofia I could really train these practices. I remember my first day in the delivery room. It was really my first day in the delivery room. They told me: ah, go over there and enter that room that a baby is going to be born. Then, I asked the preceptor who was there if I could come in and she raised her finger and said: I want... she knew I was R1, that I was going there just to look and, then, she raised her finger and said: I want absolute silence in this room, no one here is going to say a word, you will be here in the corner, just observing. I said: ok, I stayed in my place just observing. There, the woman inside a wonderful bathtub, gorgeous, the baby was born there. It was a beautiful childbirth and, like, I just cried, cried, cried a lot. The preceptor came to me and said: for God's sake, what is happening? I told her that I had never seen such a beautiful childbirth in my life. Then she hugged me and said: oh my God, which world do you come from? Then I said: Rio Grande do Sul. You don't understand what a childbirth is there. (EO3)

During the residency we already have some contact with home childbirth. There in the Sofia [Sofia Feldman Hospital] there is the home childbirth by the SUS, you know? Then, we already have contact with home childbirth in our training, with the birth center, you know? Which is that childbirth in an institution and not in a hospital. So, we already have contact. I had already had previous contact with home childbirth because I had already been to some deliveries with older nurses, as assistant, and I have always identified with home childbirth. (EO7) Once, I was doing a shift at Casa da Gestante [Sofia Fieldman Hospital] and one of the nurses said: Ah, there is a patient in labor, of HC [Home Childbirth] and who knows you want to go with us. And, then, it was January, my residency [in the Sofia Fieldman Hospital] would end in February and I said: 'Ill go! Because I know there would be the possibility of working with home childbirth in POA [Porto Alegre]. Because I didn't want to stay there, I wanted to come back here. Then I said: ah, this is my chance, I'll go! There I went. I arrived at the patient's home, she had 7 centimeters [of dilation] and it was a pregnancy II, she had already had a home childbirth of her first baby. Then, it was really quick. She was with 7, I think the baby was born in less than 2 hours we were there and it was wonderful, great. Because I didn't have this view, for being inside the hospital, that the woman was there in her shower, her bathroom, you know? Then she had a little 4-year-old daughter who stayed with her, the woman there with her stuff, you know? If she wanted anything she had available at her house, so this was something that, so, I got delighted when I saw. (EO13) 
Since 2013, the Sofia Feldman Hospital is the only one in Brazil offering planned home childbirth within the SUS, and the residency in Obstetric Nursing of the institution enabled the participant to contact this type of assistance, contributing to her decision to work in this area. Residency programs involve in-service training as a teaching-learning strategy, aiming at preparing professionals to overcome knowledge and care segmentation in health care and to meet the guidelines of the health policies that seek to change the technocratic approach of childbirth to implement humanized care actions, encourage vaginal delivery, and increase the quality indicators in maternal and neonatal care ${ }^{(13)}$.

The profile of the nurses and obstetricians trained in a residency materializes in the construction of new knowledge, with the aim of defining a space to change the obstetrics scenario, standing out for the search of autonomy and commitment, in addition to scientific knowledge to guide the evidence-based practice ${ }^{(14)}$. All these aspects were verified during the interviews with $\mathrm{EO} 3, \mathrm{EO} 7$, and $\mathrm{EO} 13$.

Training within the residency focuses on the prevailing health policies; in the case of planned home childbirth, there is no specific policy for this service in Brazil. Therefore, the residency programs in the country have probably not prepared EOs for this field. The reality of the Sofia Feldman Hospital is innovative but isolated since it is the only SUS service that covers planned home childbirth. The same must happen with the specializations, which also aim to train according to the national policies of labor and birth care, which is predominantly hospital-based.

For example, training such as doulas courses gave a new meaning to childbirth to most of the participants, promoting self-knowledge. Such experiences resulted in personal and professional changes.

I attended a doula training. The doors that Michel Odent opened, the doulas course wide opened them, it was a one-way street in my life, I say it was a turning point for me! (EO3)

[...] / attended a doulas course in 2007 with Ricardo Jones in Porto Alegre and with Zeza, and that was showing me that there was another way except for violence [...]. (EO9)

One day, I met a friend I hadn't seen for 10 years and she told me: let's take the doula course. And I said: what is that? And she explained me and said: you have to do it! And halfway through the year, three months later, there was one in Porto Alegre and I took Ricardo Jones' course and my life simply changed. From then on, all my university studies were focused on obstetrics. (EO12)
Doula (word of Greek origin meaning "the one who serves") courses usually involve group dynamics and activities related to personal experiences, positive or negative ones, so that the students get in touch with their "own phantoms" and design their own life stories, triggering emotions, personal development, and self-knowledge ${ }^{(15)}$.

A scientific research study, which aimed at analyzing how the subjectivities of women are transformed over doulas courses and training, concluded that the understanding of the participants about gestation, childbirth, and motherhood processes suffer significant changes ${ }^{(15)}$. It also highlighted that "the transformation door only opens from the inside"(15), bringing to light that, in order to enter the world of delivery and birth humanization, it is necessary to look within oneself, develop self-analysis and resignify oneself to be open to a care philosophy that transcends what is set in the Brazilian obstetric scenario. It is what seems to have happened to the EOs of this study.

Another significant finding is that many speeches echoed what was asserted by EO3 about the care model applied to childbirth in RS, which is predominantly hospital- and technocratic-based, as assumed at the beginning of this work.

Often accustomed to the hospital model, with unnecessary and harmful interventions, and witnessing obstetric violence, the EOs had to de(construct) and transform themselves personally and professionally to offer planned home childbirth assistance.

Forme, it was a big challenge [...] I have some difficulties until now, it is very difficult to deconstruct everything you had constructed in 7 years. I have already seen a lot people using Kristeller, I have already seen much violence, I have already seen much disrespect and you deconstruct all this and think that it's okay that a birth takes $12 \mathrm{~h}$, it's okay to take 20h. For me it's surreal, really surreal. It's really difficult not to interfere in the woman. They are challenges that I keep constructing, deconstructing every day and that is the best thing. It's the challenge of being a different professional for each woman. (EO4)

Actually, it was a construction, you know? Because when we work long hours within the OC, we end up thinking that the delivery goes wrong. So, it's dangerous and so on. It's a deconstruction process when you understand that, actually, what causes most of the bad events in birth is not the delivery itself but the interventions made and that cause a fatality. Something when we change, right? Of understanding that not doing an intervention protects the woman and the baby. Then we change, 
right? And it was more or less like this. It's kind of like the really traditional nurses, who want to assist birth in the model they believe, who end up going to home childbirth. Because really our model here in the state [Rio Grande do Sul] is not good, you know? Only at Conceição there's a slight opening for this insertion of the nurse, but it's not something independent, you know? So, there is always a health professional observing everything. And not in home childbirth. In home childbirth we are independent, you know? We don't ask anyone's approval for anything. It's like this. (EO7)

Obstetric violence involves all types of aggression suffered by women during labor, postpartum, and miscarriage. It can be defined by a situation in which the health professional appropriates the reproductive processes and the women's body through dehumanizing relationships, abuse of medicalization, and pathologization of natural processes, which results in the loss of autonomy and the ability to freely decide for their body and sexuality, causing a negative impact on the women's life. This type of violence involves all types of aggression suffered by women during labor, postpartum, and miscarriage ${ }^{(16-17)}$.

The speeches also show traces of the work routine within RS hospitals, where most of the interviewees worked before entering planned home childbirth. A practice that has already been proscribed in assistance is identified, the Kristeller maneuver, but that was still being practiced. Additionally, medical hegemony was mentioned in the management of delivery and birth (physician-centered care), offering a perception of continuous supervision to the EOs.

Such finding elucidated the biomedical model prevalent at the hospitals where the participants worked at a certain period. This is characterized by the physician-centered parturition assistance and the valorization of techniques that do not appreciate women's active participation ${ }^{(18)}$. For this reason, it does not facilitate the women's leading role, a fundamental aspect of humanized care ${ }^{(19)}$.

This model turns the delivery scenario into a place of disputes among physicians and obstetric nurses, causing conflicts in the EOs'daily practice, affecting the care process. It is highlighted that this situation occurs since their training, whether during the residency or the specialization, hindering the implementation of a systematized plan of Nursing assistance to parturients.

When asked about how they started working with planned home childbirth, the participants also mentioned that they were invited by other EOs, either to create a new team or to join an existing one in RS.
Actually, it has always been EO12's dream [having a team of planned home childbirth], she was looking for people to join her, I believe I was chosen. (EO5)

She invited me to make up a team with her because she was assisting by herself [without a definitive team], she used to take some assistant nurses, but she didn't have a team as she wanted to. (EO7)

The Royal College of Midwives, British organization of midwives, recommends that at least two midwives assist planned home childbirth in order to ensure safety in the assistance ${ }^{(20)}$. As there are no regulations about this aspect in Brazil, the teams of planned home childbirth in RS were created in compliance with this international recommendation; always having two nurses, with at least one of them being an EO.

Over the last years, an increasing demand of planned home childbirth in the country has been observed, mainly in the large urban centers, due to women's dissatisfaction with the current hospital-based obstetric system ${ }^{(21)}$. In RS, this demand can also be observed by the increased number of professionals working in this care modality between 2019 and 2020

Some of them were called by teams that needed a larger number of EOs to expand and safely assist women and families interested in this delivery and birth modality, in compliance with the scientific evidence and international recommendations.

[...] EO7 contacted me because there's an increasing demand of home childbirth, and they were in four in the team, and EO7 needed to have someone else, because three of the nurses also worked in hospitals. (EO11)

I started to send résumés. Then $\mathrm{EO} 3$ was my $\mathrm{R} 2$ and she was already in a home childbirth team that already had some history. I think the team was already 4 years old. [...] Then she asked me: Don't you want to enter HC? Because we need, the number of services is increasing a lot. [...] That got me quite interested, I thought it would be a great opportunity. Count me in! (EO13)

The number of women getting interested in home childbirth is increasing. It's increasing a lot and, now, with this COVID issue, home childbirth will blow up. In April and May there are many home childbirths because now women don't want to go to the hospitals [...] women are going to see now that home childbirth is truly possible and safe. (EO11) 
During COVID-19 pandemic, planned home childbirth was also impacted in RS, as well as other areas of the Nursing work. The participants highlighted the increasing search for this assistance option by the women after the outbreak of the disease in Brazil, in order to avoid the hospital environment at this time. A Brazilian research study points out that, due to the COVID-19 pandemic, Brazilian women have recognized their homes as a possible place for giving birth to their children ${ }^{(22)}$.

An international paper, which studied pregnancy and birth during the COVID-19 pandemic in the United States of America (USA), asserts that just like it happens in other health calamities, the current sanitary condition reveals the technocratic and fragmented background of the USA maternity hospitals and the increasing interest in home childbirth and independent birth centers ${ }^{(23)}$. A situation that probably was due to the exclusion of the presence of doulas and partners in hospital institutions ${ }^{(23)}$.

This has also happened, for example, during the postpartum period in Brazilian hospitals, following a new recommendation. According to Technical Note No. 09/2020 of the $\mathrm{MoH}$, it is only allowed to have a companion after delivery in exceptional cases, in which there is clinical instability of the puerperal woman, specific conditions of the newborn, or even in the case of minors. In the other situations, a temporary suspension is recommended to reduce the flow of people within the hospitals/maternity ward(24).

Based on the results and on the aforementioned research studies, it is believed that the perception of risk in planned home childbirth compared to hospital delivery is relative and marked by socio-historical moments. It may be transforming due to the experiences lived during the pandemic.

In Brazil, perhaps in a not-so-distant future, planned home childbirth may be seen as it really is by women, families, and obstetric corporations, as a feasible, low-cost option to the health system and safe to normal-risk women and newborns.

\section{The search for autonomy, freedom, protagonism, and respect in labor and birth care are stimuli for the insertion of obstetric nurses in planned home childbirth}

Believing in the planned home childbirth model, i.e., respecting the woman and her choices, being able to offer humanized care, and having availability to offer a new care model were the reasons most mentioned by the participants, as well as the disagreement with some practices, protocols, and the obstetric violence witnessed in hospital institutions.
Because it's something I believe [...] that it's safe to be born at home, that it's a more individualized assistance, respecting options, respecting the autonomy of women and families. It respects the moment. (EO2)

I think there is no better choice for the person and family to make. Of everything, respect to that woman at that moment, respecting her body, her wishes, and also respecting the birth, the physiological process of birth, the process of receiving the newborn, without unnecessary interventions. (EO6)

We saw this need for changing the very model and resignifying this moment. (EO9)

In a systematic review with a meta-analysis, it was verified that planned home childbirth of usual-risk women does not increase mortality or perinatal and neonatal morbidity compared to those who intend to give birth in a hospital ${ }^{(25)}$. When comparing the home and hospital groups, there were no differences in the following neonatal outcomes: admission at the Neonatal Intensive Care Unit (NICU), Apgar scores, and need for reanimation ${ }^{(25)}$. In usual-risk pregnant women, planned home childbirth is as safe as in a hospital ${ }^{(4)}$.

Witnessing obstetric violence scenes through words or actions and following fixed protocols and routines at institutions, even not complying with current scientific evidence ${ }^{(26)}$, encouraged the EOs to work and promote planned home childbirth as a more human and respectful care model.

Because within an institution you witness it and don't do anything. You witness a lot of obstetric violence, a lot of disrespect for the woman. A very normal way, but that it's not natural and there's nothing of normal in it. The will you have of making the difference in the life of women, of people. We need to show those people that there's another way of giving birth, with much more respect, with much more physiology, and much morelove. (EO4)

Professionals with a specialization in Obstetric Nursing can provide planned home childbirth, having the right to practice it with freedom and autonomy, provided that the pregnant woman is stratified as usual-risk ${ }^{(4)}$.

To practice this care model, the EOs need to develop technical, non-technical, and managerial competences, as well as know the legal aspects encompassing the Obstetric Nursing practice in order to ensure their autonomy and empowerment, as well as responsibly and ethically comply with their duties ${ }^{(4)}$. 
Planned home childbirth focuses on freedom, autonomy, protagonism, and respect for the philosophy and culture of women and their families ${ }^{(4)}$. Intuitively, and based on their experiences mentioned in the first category, EOs show that they acknowledge such aspects.

Because I wanted to assist more. I wanted to see a physiological delivery. I wanted to follow-up a woman from the beginning to the end. And, after we start seeing that at home they have a different labor, everything is different. That there's no external interference. And then I ended up falling in love with what I do. That's why I can't think of working in anything else. (EO10)

When they choose planned home childbirth, women and their families seek respectful, loving, safe, and quality care $^{(4)}$ and the participants show that they acknowledge that.

The childbirth care models for usual-risk women involving midwives (obstetric nurses) are related to lower intervention rates, lower risk of episiotomy, and higher parturient's satisfaction ${ }^{(4,27)}$, which reveals how beneficial the assistance carried out by professionals of this category is.

In the home setting, EOs have more autonomy to work than in hospitals, where the biomedical model is entrenched, often causing dispute situations.

And I have always felt this need of providing this differentiated assistance, making other things available to the women, things that in hospitals are not often possible, not feasible. Of course that we know that nowadays there are many hospitals offering deliveries in other positions than lithotomy and so on. But they are more assisted by the medical team, not by the Nursing team. (EO13)

Cultural, organizational, and structural issues of the hospital institutions and the working conflicts with physicians directly interfere in the autonomy of the EO. The obstetric universe works according to a net of social and power relationships influencing the care offered to women in the pregnancy-puerperal period ${ }^{(18,28)}$.

Although the Nursing legislation ensures EOs'work in an autonomous manner, including planned home childbirth, the EOs experienced privation moments when they worked in hospitals. This factor encouraged them to start providing a service that gives more autonomy, freedom, and professional protagonism to work in Obstetrics.

\section{- CONCLUSION}

The oral history of obstetric nurses in the care for planned home childbirth in Rio Grande do Sul, herein analyzed, pointed out that the training, personal, and professional experiences encouraged the professionals to start working with this care modality for women and newborns during pregnancy, delivery, birth, and puerperium.

In the personal aspect, the experience of home childbirth was one of the contributing factors. In the training scope, a residency program in Obstetric Nursing and free doula courses were stimuli for their decision to work with planned home childbirth. In the professional realm, the obstetric nurses witnessed and experienced obstetric violence and restrictions to work with autonomy and freedom in labor and birth care, being determinants for them entering this service.

The oral history of the obstetric nurses revealed that what was experienced led them to look within themselves and resignify themselves to awaken to the practice of a new modality of obstetric care in their routines. Dissatisfaction with the hospital obstetric care in RS emerged in the speeches, highlighted as interventionist and physician-centered, encouraging obstetric nurses to start working with planned home childbirth. The professionals showed that they believe in the humanized model, seeking to respect the physiology, choices, and protagonism of the women/families in the parturition process.

In addition to that, autonomy and freedom are factors that affect both sides: women in the face of their pregnancy and delivery, and obstetric nurses, for being able to experience planned home childbirth according to the paradigm they believe and defend.

It is worth noting that this is the first study revealing the overview of planned home childbirth teams of Rio Grande do Sul, which currently assists women and their families against the country's prevailing technocratic paradigm. Therefore, it is challenging and necessary to bring up a care model in obstetrics centered on the woman and not on the professional, in a predominantly technocratic scenario, and to problematize a polemic theme like planned home childbirth.

In view of that, it is concluded that revealing the insertion trajectory of obstetric nurses in the assistance to planned home childbirth in Rio Grande do Sul is a beginning to start (re)thinking about the work of Obstetric Nursing in different areas of the State health system and giving voice to those who are at the forefront of home delivery and birth humanization. 


\section{REFERENCES}

1. Ministério da Saúde (BR). Nascidos vivos - Rio Grande do Sul. Brasília, DF: Datasus; 2018 [cited 2020 May 15]. Available from: http://tabnet.datasus.gov. br/cgi/tabcgi.exe?sinasc/cnv/nvrs.def

2. Davis-Floyd R. The technocratic, humanistic, and holistic paradigms of childbirth. Int J Gynaecol Obstet. 2001;75 Suppl1:S5-S23. doi: https://doi. org/10.1016/S0020-7292(01)00510-0

3. Conselho Federal de Enfermagem (BR). Resolução COFEN no 516/2016. Normatiza a atuação e a responsabilidade do Enfermeiro, Enfermeiro Obstetra e Obstetriz na assistência às gestantes, parturientes, puérperas e recém-nascidos nos Serviços de Obstetrícia, Centros de Parto Normal e/ou Casas de Parto e outros locais onde ocorra essa assistência e estabelece critérios para registro de títulos de Enfermeiro Obstetra e Obstetriz no âmbito do Sistema Cofen/Conselhos Regionais de Enfermagem. Brasília: COFEN; 2016 [cited 2020 Jun 21]. Available from: http://www.cofen.gov.br/resoluca0-cofen-no-05162016_41989.html

4. Mata JAL. Enfermagem obstétrica no parto domiciliar planejado: responsabilidade legal e organização do serviço. In: PROENF: Saúde Materna e Neonatal. Porto Alegre: Artmed/Panamericana; 2017. p. 75-125.

5. Campbell K, Carson G, Azzam H, Hutton E. No. 372 - Statement of planned homebirth. J Obstet Gynaecol Can. 2019 [cited 2020 Jun 15];41(2):223-7. Available from: https://themidwivesclinic.ca/site/wp-content/uploads/ Planned-home-birth-statement-.pdf

6. Gil AC. Como elaborar projetos de pesquisa. 6. ed. São Paulo: Atlas; 2017.

7. Mata JAL, Shimo AKK. A arte de pintar o ventre materno: história oral de enfermeiras e obstetrizes. Enferm Actual Costa Rica. 2018 [cited 2020 Jun 28];(35):1-23. Available from: http://www.scielo.sa.cr/scielo. php?script=sci_arttext\&pid=S1409-45682018000200001

8. Alberti V. Manual de história oral. 3. ed. Rio de Janeiro: Editora FGV; 2013.

9. Bardin L. Análise de conteúdo. Lisboa: Edições 70; 2011.

10. Ministério da Saúde (BR). Conselho Nacional de Saúde. Resolução nº 510, de 07 de abril de 2016. Dispõe sobre as normas aplicáveis a pesquisas em Ciências Humanas e Sociais cujos procedimentos metodológicos envolvam a utilização de dados diretamente obtidos com os participantes ou de informações identificáveis ou que possam acarretar riscos maiores do que os existentes na vida cotidiana. Brasília, DF; 2016 [cited 2020 May 20] Available from: https:// conselho.saude.gov.br/resolucoes/2016/Res0510.pdf

11. Muñoz-Dueñas C, Contreras-García Y, Manríquez-Vidal C. Vivencias de mujeres con asistencia de parto personalizado. Rev Chil Obstet Ginecol. 2018;83(6):58695. doi: https://doi.org/10.4067/S0717-75262018000600586

12. Larkin P, Begley CM, Devane D. Women's preferences for childbirth experiences in the Republic of Ireland; a mixed methods study. BMC Pregnancy Childbirth. 2017;17:19. doi: https://doi.org/10.1186\%2Fs12884-016-1196-1

13. Pereira ALF, Guimarães JCN, Nicácio MC, Batista DBS, Mouta RJO, Prata $J A$. Perceptions of nurse-midwives of their residency training and professional practice. Rev Min Enferm. 2018;22:e1107. doi: https://doi. org/10.5935/1415-2762.20180035

14. Fernandes e Silva F, Moura MAV, Almansa Martinez P, Souza IEO, Queiroz ABA, Pereira ALF. Training in the obstetric nursing residency modality: a hermeneuticdialectic analysis. Esc Anna Nery. 2020. 24(4):e20190387. doi: https://doi. org/10.1590/2177-9465-ean-2019-0387
15. Silva FL, Russo JA. A porta da transformação só abre pelo lado de dentro: notas etnográficas sobre o processo da (trans)formação de si em cursos de capacitação de doulas. Cad Gênero Divers. 2019 [cited 2020 May 14];5(4):162-80. Available from: https://cienciasmedicasbiologicas.ufba.br/index.php/cadgendiv/article/ view/29456/20641

16. Brandt GP, Souza SJP, Migoto MT, Weigert SP. Violência obstétrica: a verdadeira dor do parto. Rev Gestão Saúde. 2018 [cited 2020 Jun 28];19(1):19-37. Available from: http://www.herrero.com.br/files/revista/ file2a3ed78d60260c2a5bedb38362615527.pdf

17. Tesser CD, Andrezzo HFA, Diniz SG, Knobel R, et al. Violência obstétrica e prevenção quaternária: 0 que é e o que fazer. Rev Bras Med Fam Comun. 2015;10(35):1-12. doi: https://doi.org/10.5712/rbmfc10(35) 1013

18. Santos FAPS, Enders BC, Brito RS, Farias PHS, Teixeira GA, Dantas DNA, et al. Autonomy for obstetric nurse on low-risk childbirth care. Rev Bras Saúde Mater Infant. 2019;19(2):471-9. doi: https://doi. org/10.1590/1806-93042019000200012

19. Silva U, Fernandes BM, Paes MSL, Souza MD, Duque DAA. Nursing care experienced by women during the childbirth in the humanization perspective. J Nurs UFPE. 2016 [cited 2020 Aug 20];10(4):1273-9. Available from: https:// periodicos.ufpe.br/revistas/revistaenfermagem/article/viewFile/11113/12587

20. Royal College of Midwives (UK). The Role and Responsibilities of Maternity Support Workers. London: RCM; 2016 [cited 2020 May 15]. Available from: https://www.rcm.org.uk/media/2338/role-responsibilities-maternitysupport-workers.pdf

21. Cursino TP, Benincasa M. Parto domiciliar planejado no Brasil: uma revisão sistemática nacional. Ciênc Saúde Coletiva. 2020;25(4):1433-44. doi: https:// doi.org/10.1590/1413-81232020254.13582018

22. Volpato F, Costa R, Lima MM, Verdi MIM, Gomes IEM, Scapin SP. Parto domiciliar planejado no contexto da covid19: informações para a tomada de decisão. SciELO Preprints 496 [Preprint]. 2020 [cited 2020 Jun 10]. Available from: https://preprints.scielo.org/index.php/scielo/preprint/view/496/version/506 doi: https://doi.org/10.1590/SciELOPreprints.496

23. Davis-Floyd R, Gutschow K, Schwartz DA. Pregnancy, birth and the COVID-19 pandemic in the United States. Med Anthropol. 2020;39(5):413-27. doi: https://doi.org/10.1080/01459740.2020.1761804

24. Ministério da Saúde (BR). Secretaria de Atenção Primária à Saúde Departamento de Ações Programácas Estratégicas Coordenação-Geral de Ciclos da Vida Coordenação de Saúde das Mulheres. Nota Técnica No 9/2020-COSMU/CGCIVI/ DAPES/SAPS/MS. [Dispõe sobre as] recomendações para o trabalho de parto, parto e puerpério durante a pandemia da covid-19. Brasília, DF; 2020 [cited 2020 Jun 10]. Available from: https://portaldeboaspraticas.iff.fiocruz.br/wpcontent/uploads/2020/04/SEl_MS-0014382931-Nota-Tecnica_9.4.2020_ parto.pdf

25. Hutton EK, Reitsma A, Simioni J, Brunton G, Kaufman K. Perinatal or neonatal mortality among women who intend at the onset of labour to give birth at home compared to women of low obstetrical risk who intend to give birth in hospital: a systematic review and meta-analyses. EClinicalMedicine. 2019;14:59-70. doi: https://doi.org/10.1016/j.eclinm.2019.07.005

26. Sanfelice CFO, Abbud FSF, Pregnolatto OS, Silva MG, Shimo AKK. From institutionalized birth to home birth. Rev Rene. 2014;15(2):362-70. doi: https://doi.org/10.15253/2175-6783.2014000200022 
27. Sandall J, Gates S, Soltani H, Shennan A, Devane D. Midwife- led continuity models versus other models of care for childbearing women. Cochrane Database Syst Rev. 2015;15(9):CD004667. doi: https://doi.org/10.1002/14651858. CD004667.pub4

\section{- Authorship contribution:}

Project Management: Júnia Aparecida Laia da Mata.

Investigation: Luciana Makarevicz Santos, Júnia Aparecida Laia da Mata, Alessandra Vaccari.

Methodology: Luciana Makarevicz Santos, Júnia

Aparecida Laia da Mata.

Data curation: Júnia Aparecida Laia da Mata, Clara Fróes de Oliveira Sanfelice.

Formal analysis: Luciana Makarevicz Santos, Júnia Aparecida Laia da Mata.

Supervision: Júnia Aparecida Laia da Mata, Alessandra Vaccari.

Writing - Original draft: Luciana Makarevicz Santos, Júnia Aparecida Laia da Mata, Alessandra Vaccari, Clara Fróes de Oliveira Sanfelice.

Writing - Review and editing: Júnia Aparecida Laia da Mata.

\section{- Corresponding author:}

Júnia Aparecida Laia da Mata

Email: jumata.2905@gmail.com
28. Amaral RCS, Alves VH, Pereira AV, Rodrigues DP, Silva LA, Marchiori GRS. The insertion of the nurse midwife in delivery and birth: obstacles in a teaching hospital in the Rio de Janeiro state. Esc Anna Nery. 2019;23(1):e20180218. doi: https://doi.org/10.1590/2177-9465-ean-2018-0218
Associate editor:

Dagmar Elaine Kaiser

\section{Editor-in-chief:}

Received: 07.01.2020

Maria da Graça Oliveira Crossetti 